\title{
The paradiplomacy of subnational governments in North America*
}

\author{
La paradiplomacia de los gobiernos subnacionales en \\ América del Norte \\ A paradiplomacia dos governos subnacionais na América do Norte
}

Received on July 12, 2017.Accepted October 23, 2017

Roberto Zepeda Martínez**

México

, To cite this article:

Zepeda Martínez, Roberto

(junio, 2018). The paradiplomacy

of subnational governments in

North America. Ánfora, 25(44),

17-41. Universidad Autónoma

de Manizales. ISSN 0121-6538.

\section{Abstract}

Objective: to determine the factors that have contributed to the expansion in the international activities of the subnational actors and to identify the issues that prevail in the relations between the Canadian provinces and the subnational states of North America. Likewise, to identify the strategies and mechanisms that favor the relationships between these subnational governments. Methodology: the qualitative methodological strategy comprises of two dimensions: the first focuses on the factors which explain these dynamics and on the conceptual revision to refer to the transnational activities of subnational governments in North America, in particular the paradiplomacy. The second one examines official information, reports and publications from national and subnational governments in the region. Subsequently,

\footnotetext{
* This article is derived from the project: "Subnational dynamics in North America: relations of the noncentral governments of Canada with their counterparts in the United States and Mexico", carried out at the CISAN-National Autonomous University of Mexico, UNAM . Project in progress, started in September 2015.

** Doctor in Political and Social Sciences. Full-time Researcher at the Research Center on North America (CISAN) of the National Autonomous University of Mexico, UNAM. Email: zepeda_roberto@hotmail.com
} 
the international activities of these governments were examined to determine their nature, characteristics and objectives. Results: it was highlighted that the international activities of subnational governments are linked to economic development and to issues such as the environment, natural resources, sustainable development, security, culture, education, science and technology. They are carried out through institutional deliberation and decision-making forums, international offices and cooperation agreements. Conclusions: subnational governments contribute to the governance of North America, through the formulation of regional public policies to face common challenges. The agreements are limited in the areas of jurisdiction of the subnational governments and, at the same time, they show/disclose a certain degree of autonomy with respect to the central government.

Keywords: Paradiplomacy; International cooperation; Public policies.

\section{Resumen}

Objetivo: determinarlosfactores quehan contribuidoala expansión delas actividades internacionales de los actores subnacionales y detectar los temas que predominan en las relaciones entre las provincias canadienses y los estados subnacionales de América del Norte. Asimismo, identificar las estrategias y mecanismos con los cuales se dan las relaciones entre estos gobiernos subnacionales. Metodología: la estrategia metodológica de tipo cualitativo comprende dos dimensiones: la primera, se enfoca en los factores que explican estas dinámicas y en la revisión conceptual usada para hacer referencia a las actividades transnacionales de los gobiernos subnacionales en América del Norte, en particular la paradiplomacia. La segunda, escudriña información oficial, reportes y publicaciones de los gobiernos nacionales y subnacionales de la región. Posteriormente, se examinaron las actividades internacionales de tales gobiernos para determinar su naturaleza, características y objetivos. Resultados: se evidenció que las actividades internacionales de los gobiernos subnacionales están vinculadas con el desarrollo económico y con temas como medio ambiente, recursos naturales, desarrollo sustentable, seguridad, cultura, educación, ciencia y tecnología; se llevan a cabo a través de foros institucionales de deliberación y toma de decisiones, oficinas internacionales y acuerdos de cooperación. Conclusiones: los gobiernos subnacionales contribuyen a la gobernanza de América del Norte, a través de la formulación de políticas públicas regionales para afrontar retos comunes. Los acuerdos se circunscriben en las áreas de jurisdicción de los gobiernos subnacionales y, al mismo tiempo, revelan cierto grado de autonomía respecto al gobierno central.

Palabras clave: Paradiplomacia; Cooperación internacional; Políticas públicas. 


\section{Resumo}

Objetivo: determinar os fatores que tem contribuído à expansão das atividades internacionais dos atores subnacionais e detectar as temáticas que dominam nas relações entre as províncias canadenses e os estados subnacionais da América do Norte. Além disso, identificar as estratégias e mecanismos com os quais as relações entre esses governos subnacionais são dadas. Metodologia: a estratégia metodológica de tipo qualitativo compreende duas dimensões: a primeira se enfoca nos fatores que explicam estas dinâmicas e na revisão conceitual usada para se referir às atividades transnacionais dos governos subnacionais na América do Norte, particularmente na paradiplomacia. A segunda, examina informações oficiais, relatórios e publicações dos governos nacionais e subnacionais da região. Posteriormente, as atividades internacionais de tais governos foram examinadas para determinar sua natureza, características e objetivos. Resultados: Evidenciou-se que as atividades internacionais dos governos subnacionais estão ligadas ao desenvolvimento econômico e a questões como o ambiente, recursos naturais, desenvolvimento sustentável, segurança, cultura, educação, ciência e tecnologia; estas são realizadas através de fóruns institucionais de deliberação e tomada de decisões, acordos de cooperação, e em escritórios internacionais. Conclusões: os governos subnacionais contribuem à governação da América do Norte, através do desenvolvimento de políticas públicas regionais para enfrentar os desafios comuns. Os acordos se circunscrevem nas áreas da jurisdição dos governos subnacionais e, ao mesmo tempo, revelam um grau de autonomia do governo central.

Palavras-chave: Paradiplomacia; Cooperação internacional; Políticas públicas. 


\section{Introduction}

Since the last quarter of the twentieth century, the growing economic globalization has generated unprecedented challenges that mostly exceed the maneuverability of the State, and thus, leading to a new form of governance. Therefore, new spaces for power and decision-making have emerged. In this context, the subnational states ${ }^{1}$ have arisen as one of the most relevant actors of the 21 st century, at an international level. The important global problems have not been solved from the central governments, but they find streams of solutions in the subnational governments.

Since the entry, in force, to the North American Free Trade Agreement (NAFTA) in 1994, its commercial relations have been strengthened. The countries of this free trade zone - Mexico, the United States and Canada produce around $30 \%$ of the goods and services in the world. Trade in the region is at least $265 \%$ larger than two decades ago, when NAFTA came into force, as investment has multiplied by six (Secretary of Foreign Affairs [SFA], 2014). However, there has been no relevant progress in other forms of integration. In other words, the national governments of these three countries have set aside regional integration in North America. Nevertheless, the relations between subnational governments have expanded in different areas, and have developed collaborative networks, which are of utmost importance to understand the emerging dynamics and emerging realities within the region.

Some authors have delved into the paradiplomacy of subnational governments in the region. For example, international activities such as trade in the Canadian provinces with Kukucha (2009) or the role of the Canadian provinces regarding the implementation of treaties with Paquin (2010); in addition to this, the specific case of Quebec's motivations in its international strategy raised by Balthazar (1999). In the case of the United States, the role of subnational governments as international actors has been examined by various authors, considering the relevance and characteristics of their international dynamics (Hocking, 1993, Fry, 2004, McMillan, 2012). However, a regional perspective has not been proposed that reckons upon international relations between the subnational governments of Canada and the United States, established through different cooperation plans.

Thus, the question arises whether the process of economic integration in North America has led to a rise in international relations between the subnational

1. To avoid confusion, in this article the term "state" (in lowercase) refers to federal entities or subnational units of countries with a federal system, for example, the states of Mexico and the United States, as well as the provinces of Canada. While "State" (in capital letters) is used as a synonym for country or "nation-state", for example, Mexico, the United States and Canada. 
governments in the region and how these trends have been displayed in the countries of the region.

\section{Methodology}

This paper used a qualitative methodological strategy that comprises of two dimensions of observation and analysis. The first dimension includes the conceptual approaches review which are used in political science and international relations to refer to transnational activities of subnational governments, particularly, the concept of paradiplomacy. In addition, a review of perspectives to explain these dynamics, such as federalism, decentralization, globalization and governance. The second dimension consists of a detailed analysis of official information, reports and data from primary sources that are brought about by both national and subnational governments of the region. For example, regional organizations ${ }^{2}$ that are part of subnational governments and the official websites of subnational governments that account for their international activities. Likewise, from the Ministry of Foreign Affairs of Mexico, and from the Mexican Embassy in the United States.

The analysis of the time period is focused from the middle of the $1980 \mathrm{~s}$ until 2015, due to the identification of diverse processes such as economic globalization and decentralization, which intensified during this period. For example, economic integration and neoliberal policies increased from the implementation of the Free Trade Agreement between the United States and Canada (1988), as well as the North American Free Trade Agreement (NAFTA) between the United States, Canada and Mexico. The analysis strategy focuses on the international relations of Canada's provinces with subnational governments in the United States.

\section{Results}

Different factors have contributed to the expansion of the international relations of subnational governments in North America, particularly between the subnational governments of Canada and their counterparts in the United States. The first section shows the results of some key features of federalism,

2. For example, the Conference of Governors and Premiers of the Great Lakes and San Lorenzo (CGLSLGP), the Alliance between states of the Southeast of the United States and the Canadian Provinces (SEUS-CP), among others. 
particularly the levels of decentralization in the countries of North America. The second section focuses on the features, dynamics, and most relevant actors of governance, as well as the State fragmentation, that shows the expansion of new centers of power and authority

Likewise, these results exhibit how neoliberal globalization has affected subnational governments, and thus how it has led to processes such as subnational internationalization and the emergence of regional or transnational governance agreements. Finally, it has shown the concept of paradiplomacy with its different forms and features, particularly in North America. In the third section, it's discussed the dimension of the paradiplomacy of the Canadian provinces and the states of the United States. Cross-border cases are noted among the subnational states of the region, which lead to permanent forums that have been institutionalized in some cases.

Subsequently, the paradiplomacy dimensions of the Canadian provinces are shown and discussed and the issues fostering these trends are highlighted. Paradiplomacy activities within the region have increased because of economic globalization, however these have been more noticeable in countries with high levels of decentralization that have given greater influence and room for maneuver to subnational actors in the international arena.

An expansion of international relations between subnational governments in North America has been identified over the last two decades. This has been associated with the economic and commercial activities of the subnational region, and it derives from transnational cooperation in such varied topics as environment, natural resources, sustainable development, security, culture, education, science and technology as well. Most of the agreements and public policies that have been finalized are limited to the areas of subnational jurisdiction and, they also exhibit a certain degree of autonomy with respect to the central government.

In some cases, subnational governments pursue self-governing objectives of national governments, especially in those provinces that consider themselves as a nation within a State, which is the case Quebec in Canada, however, this trend has decreased in recent years. The international actions of subnational governments contribute to solve regional problems and at the same time deal with global problems that have not been solved at the national level. Regarding the region governance, the participation of subnational governments in transnational cooperation settings with other subnational units stands out. This sometimes becomes institutional forums to coordinate efforts to face common challenges in different areas.

A combination of factors has contributed to the expansion of subnational governments' international activities. It is recognized that subnational 
governments have a wide margin of maneuver in countries with federal systems and with a high level of decentralization. In addition, neoliberal globalization has eroded the power of the nation-State and new actors have emerged in the international system. This has resulted in a new form of governance with a great range of actors and among these, the role of subnational governments is highlighted, which have established interaction networks with their counterparts in the same region, and from distant countries. The next section focuses on such factors.

\section{Federalism and decentralization}

It is relevant to inquire into the features of federalism, due to the wide capacity the subnational governments of countries under this system in which they have to formulate public policies in several areas, which include the international development activities. The three North American countries have federal systems of government; however, each country has different levels of decentralization between central and non-central governments. Fry (2004, p.4) notes that Canada has the most decentralized system, with the governments of the 10 provinces exerting greater powers in the formulation of public policies, compared to those of the 50 states of the United States or the 32 states of Mexico. In addition, each country has a different historical evolution of federalism, particularly in Mexico, where it has prevailed a central tendency in the political life of the country. Canada can be regarded as the country with one of the most decentralized federal systems in the world (Hague and Harrop, 2005, p. 232).

The emergence and historical development of federalism differs among the countries of the region. For example, the United States and Canada emerged as countries formed by subnational governments with certain autonomy with respect to the central government, while federalism in Mexico, arose from a centralist government (Curzio, 2000, Márquez-Padilla, 2012) ${ }^{3}$. Canada is characterized by having a multicultural, multinational and bilingual federalism (Burgess, 2006: 120); that is, Canada is a very diverse country, where such diversity of government is recognized, which explains the high degree of decentralization and autonomy in its provinces.

3. For further information on the characteristics of federalism in the United States, see: Paz-Consuelo Márquez-Padilla (2012), International Justice: Ideas and Reflections, Mexico, CISAN-UNAM. Regarding the case of Mexico, see: Leonardo Curzio (2000), "Mexican federalism: balance and perspectives", in Guillermo Ibarra and Ana Luz Ruelas (eds.), Mexico and Canada in globalization: stressed borders in North America, Mexico: Porrúa, pp.257-280. 
According to the United Nations Development Program (UNDP), decentralized governance if carefully planned, effectively implemented and properly managed can lead to a significant improvement in the well-being of people at the local level and its cumulative effect can also strengthen human development. Although, decentralized governance is neither a panacea nor a quick solution (2004, p.2). This same organization ensures that the key to a favorable decentralized governance to human development is to ensure that the voices and demands of the poor, especially women, contribute to its design, execution and monitoring. Likewise, Fry (2011) argues that subnational governments are more receptive to the needs of citizens and are more adapted to their problems; therefore, transferring responsibilities to lower levels of government can contribute to a more effective and efficient formulation of public policies.

In Canada, the provinces administer the health, education, social benefits, and work systems, among other expenses (see table 1). In 2011 , about $47 \%$ of public expenditure was focused on the provincial level in Canada (the highest percentage in this category among OECD countries), whilst the local government focused $20 \%$ and the federal government $28 \%$, of the public expenditure (OECD, 2015). These powers of the provinces allow them to design the implementation of international treaties that affect the expenditure under their jurisdiction (Paquin, 2010). In turn, Hale (2012) showed that a series of judicial decisions since the nineteenth century has given the provinces significantly greater jurisdiction and discretion in areas of public policy ranging from economic development to the regulation of labor relations, capital markets, and natural resource development.

According to Kincaid (2013, p.111), the 50 states of the United States have limited powers to carry out international activities derived from three factors: 1) their constitutional authority to engage in the international arena in a limited manner as states, instead of as State-nations; 2) the political freedom to pursue state and local interests at the international level; 3) the governmental capacity to act independently in the international arena. In addition, Kincaid stands out an expansion of international activities in the last decades of the 2oth century; the states sought to promote their exports and attract foreign investment due to economic stagnation. The international actions of the subnational states have mainly focused on trade and economic development 

Ánfora, 25(44), 17-41. Universidad Autónoma de Manizales. ISSN 0121-6538.

Table 1. Powers of the provinces and the central government in Canada

\begin{tabular}{|c|c|c|}
\hline $\begin{array}{l}\text { Exclusive jurisdiction of the } \\
\text { provinces }\end{array}$ & $\begin{array}{l}\text { Exclusive jurisdiction of the } \\
\text { federal government }\end{array}$ & $\begin{array}{l}\text { Shared powers of the } \\
\text { federal and provincial } \\
\text { governments }\end{array}$ \\
\hline Direct taxes & $\begin{array}{l}\text { Peace, order and good } \\
\text { government }\end{array}$ & Immigration \\
\hline $\begin{array}{l}\text { Crown lands and natural } \\
\text { resources }\end{array}$ & Any form of taxes & Agriculture \\
\hline $\begin{array}{l}\text { Hospitals (healthcare } \\
\text { sector) }\end{array}$ & $\begin{array}{l}\text { International and interpro- } \\
\text { vincial commerce, communi- } \\
\text { cations and transport }\end{array}$ & Pensions \\
\hline Education & Banking and currency & \\
\hline Benefits & Foreign affairs (treaties) & \\
\hline Municipalities & Militia and defence & \\
\hline Local work & $\begin{array}{l}\text { Criminal legislation and } \\
\text { penitentiary system }\end{array}$ & \\
\hline $\begin{array}{l}\text { Business and intra- } \\
\text { provincial transport }\end{array}$ & Naturalization & \\
\hline $\begin{array}{l}\text { JUSTICE } \\
\text { ADMINISTRATION }\end{array}$ & $\begin{array}{l}\text { Weights, measures, copyri- } \\
\text { ghts and patents }\end{array}$ & \\
\hline Civil and property rights. & First Nations & \\
\hline \multirow{4}{*}{$\begin{array}{l}\text { Cooperatives and savings } \\
\text { banks. }\end{array}$} & Residual powers & \\
\hline & Declarative power. & \\
\hline & Denial and reservation. & \\
\hline & $\begin{array}{l}\text { Unemployment insurance } \\
\text { and old-age pensions. }\end{array}$ & \\
\hline
\end{tabular}

Source: Bélanger (2008).

It is remarkable that the decentralization tendencies noted in North America have also been presented in Latin America, although to a lesser extent. Naim (2013) warns that the increase of democratic countries in Latin America has contributed to a higher level of decentralization. The number of Latin American countries in which the executive authorities of local governments (mayors) are elected directly by the population, and not designated by the central authorities, increased in 1980 from 3 to 17 in 1995. In addition, Naim states that according to 
the Inter-American Development Bank (IDB), subnational governments in the region went from managing $8 \%$ of public expenditure in 1990 to $15 \%$ in 2005.In the most decentralized countries, the proportion was much higher: around $40 \%$ of state expenditure in Argentina, Brazil and Colombia is no longer controlled by the central power.

In the case of Mexico, according to a study from the OECD (2013), in 2009 the governments of the states and municipalities in this country exercised about $38 \%$ of the total public expenditure, while the federal government concentrated a little more than $60 \%$ of such expenditure. In fact, the proportion of public expenditure exerted by subnational governments has increased in recent decades. For example, in 1990, the states and municipalities together accounted for $10 \%$ of public expenditure in Mexico. This percentage increased to 40\% in 2009. According to this study, the increase in spending by subnational governments coincided with a greater number of federal transfers for particular purposes.

However, the processes of political decentralization do not always lead to more efficient public policies, especially in those countries that have not been democratically consolidated and with lasting unclear practices. For example, the process of decentralization of police forces initiated in Mexico in the 1990s has not led to greater security in the country. Similarly, the decentralization of the education system since the late 1980 s has not created a better education system, especially at the basic level.

In this way, federalism and decentralization are important factors that give room for maneuver to subnational governments to participate in the formulation of public policies and to conduct international activities. These trends have expanded in recent decades as a result of the neoliberal economic globalization that has led to a fragmentation of the State, thus, giving rise to new forms of governance. In the North American countries, such tendencies have been more observable in the United States and Canada, whilst Mexico has been left behind by the factors mentioned above.

\section{Governance and State fragmentation}

Governance can be defined as "la suma de regulaciones generadas por actores, procesos, así como estructuras y justificada con referencia a un problema público" (Zürn et al, 2010, p. 2). Governance involves actors and processes that are part of a plan of action which includes political negotiations, coalition building, advocacy (lobbying), persuasion and threats that accompany the formulation and implementation of public policies. On the other hand, research on multi-level governance has brought renewed interest in subnational units, departments and urban areas. Subnational levels are regarded as "poly-centric" governance 
arrangements or as competent and overlapping functional jurisdictions that play an important role within a multi-level context (Zürn et al, 2010, p.(7)

Although there is no exact or single definition, in general terms, governance refers to the different forms through which social life is coordinated. Governance is therefore a process (or a complex of processes); its main modes include markets, hierarchies, and networks. Governance is represented by an unclear distinction between the State and society (private organizations and institutions work together with public ones) and the participation of several levels and layers (potentially local, provincial, national, regional and global). The processes through which international affairs are coordinated are increasingly identified as "global governance" (Heywood, 2010, p.25)

Some authors have warned that the national government is increasingly limited by a multilevel system of governance -local, national, regional and global-, which can hardly be monitored, or rather, controlled. For example, Rosenau observes that global problems are governed through a bifurcated system in which there are two worlds of global politics: the first one, an interstate system of Estates and their national governments that has long dominated the course of events; and the second one, a multicentric system of diverse types of collectivities that has emerged recently as an opposing source of authority, with actors that sometimes cooperate and sometimes compete, but that interact continuously with the Estate-centrist system (Rosenau, 2003, p.225).

Currently, Scholte (2005) states that governance involves supra-state regimes (regional and transnational) which operate with some autonomy from the State (p. 186). In addition, many sub-state governments (municipal and provincial) are directly involved with spheres beyond the national scope. In other words, governance in the globalized world of the 21 st century has become indistinctly interlaced and multilevel. Regulation occurs in and through connections between global, regional, national, provincial and municipal settings. No level predominates over the other, as it did with the primacy of the State over substate settings in territorial circumstances.

In this way, in the globalized world, society is regulated in a polycentric way, in which governance tends to be diffused, emanating from multiple points at the same time, with points and lines of authority that are not always clear (Scholte, 2005, p. 186). Governance dispersion occurs not only from the local to the global, but also given through regulatory mechanisms in private sectors, alongside the public sector. This multilayer situation and diffusion of governance could be called "polycentrism", to denote its distinctive characteristic of emanating from multiple points at the same time (Scholte, 2005).

That is to say, there has been a fragmentation of the State, with a decentralizing tendency that gives more influence and power to subnational governments to 
operate both in the national and international arena. The sources of authority of the multi-centric world warned by Rosenau (2006) include subnational governments, among other actors, which become centers of power and authority in different ways. In this regard, the growing activity of subnational actors in the international sphere is largely the result of the restructuring that the State has undergone in a context of economic globalization and political decentralization.

In this context, subnational governments have become one of the most important actors in regional governance, which manifests itself in various forms of transnational cooperation. Likewise, globalization has been accompanied by neoliberal policies, which have impacted subnational governments, leading them to seek sources of economic development abroad. The internationalization of subnational governments is due, in part, to the application of neoliberal policies, as shown in the next section

\section{Globalization and subnational governments}

Economic globalization and governance have rebuilt the role of subnational governments in several ways. For example, John Pierre (2013, p.17) states that, during the 1990s, globalization - along with a neoliberal regime that led to unequal economic development among cities and regions - represented a significant challenge for subnational governments. The author highlights that the impact of globalization on states, regions and cities has become increasing articulated. This impact has been stronger and more direct in subnational economies and institutions than in national political economies.

In addition, Pierre (2013) claims that globalization has coincided with, and often favorably, important processes of domestic institutional change. The economic policies of the State in Western democracies during the $1980 \mathrm{~s}$ and 1990 s have increasingly emphasized on neoliberal goals, such as tax cuts, deregulation and public-sector cuts. ${ }^{4}$. These policies tend to leave cities and regions less protected from international economic pressures and international policies, unlike the type of public policies that previously prevailed, for example, higher taxes, more regulation, and a more intervening public sector with more resources. In this way, subsidies from the central government to subnational

\footnotetext{
4. Neo-liberal policies were identified by John Williamson at the end of the decade of the 1980s and represent specifically what is known as the Washington consensus: (1) Fiscal discipline, (2) Inflation as main patterns of the economy, (3) Priorities in public spending, (4) Tax reform, (5) Interest rates (6) Type of exchange rate, (7) Trade policy, (8) Foreign Direct Investment (FDI), (9) Privatization, (10) Deregulation. For further details of neoliberalism, see: Roberto Zepeda (2013), Neoliberalismo, desempeño económico y mercados laborales en Latinoamerica: un enfoque comparativo, Ánfora, vol. 20, núm. 35, julio-diciembre, pp. 13-40.
} 
governments used to be more constant and generous. These stimuli were intended to compensate cities and regions for the implementation of national public policies.

The combined effect of neoliberal policies of central government and the reduction of subsidies from central governments to subnational governments has led many cities and regions to explore other sources of income and economic development, including networks abroad ${ }^{5}$. The era of globalization has led to an institutional restructuring that generates processes such as subnational internationalization, and the emergence of regional or transnational governance agreements. Likewise, subnational internationalization is clearly linked to globalization. It encourages cities and regions to seek strategic alliances abroad and indirectly through the neoliberal policy of inspiring competition between cities and regions (Pierre, 2013).

Similarly, Lachapelle and Paquin (2005) claim that the nation-State is the victim of globalization and that its capacity to regulate the national economy has been significantly reduced. For these authors, the authority is fragmented between different public and private actors, on international, national, regional and local contexts. Globalization is changing the rules of the game for all players, and this situation is creating space for new strategies, new operating methods and new possibilities for governance.

According to this scene, it is evident that the effects of globalization have undermined the ability of the government to respond to an increasing number of public policy issues. As a result, subnational governments have not been favored and have had to seek other forms of economic development within the international context. Several authors have conceptualized international relationships of subnational governments as paradiplomacy. The following section analyzes different meanings of this term, its forms and characteristics, especially in North America. Paradiplomacy is an essential element of regional governance in North America, in other words, spaces of governance are created through paradiplomacy.

\section{Paradiplomacy}

As it has been mentioned, subnational governments have seen an increase in power and influence in a decentralization context and fragmentation of the State, and creates new forms of regional governance. Subnational governments have increased their international activities due to these conditions. According

5. For further details about how globalization has affected the sub-national Governments and has motivated them to expand their activities in the international arena, see: Jon Pierre (2013). Globalization and governance. Edward Elgar Publishing. 
to Kuznetsov (2015), paradiplomacy refers to the participation or involvement of constituent units (regions) of national States in International Affairs, such as the provinces in Canada, the states in the United States, autonomous communities in Spain, landers in Germany, the oblasts, and the republics in Russia.

In this sense, regional governments carry out international relations activities in different ways: "to establish commercial and cultural missions abroad, sign treaties and agreements with international state and non-state actors, participate in international networks of regional cooperation, and sometimes, to ask official foreign policy of their central governments through speeches or actions" (Kuznetsov 2015, p.3)

For Noe Cornago (2013) paradiplomacy involves the participation of noncentral governments in international relations through the establishment of permanent or ad hoc contacts with foreign public or private entities, thus in order to promote socio-economic or cultural issues, as well as any other external dimension of their constitutional competences.

Ivo Duchacek (1990), one of the first authors to use the term, identifies three different forms of paradiplomacy. Firstly, cross-border regional paradiplomacy refers to cross-border contacts - institutional, formal, and above all, informal contacts - that are determined by geographical proximity and nature of common problems and their possible solutions. Secondly, trans-regional paradiplomacy refers to connections and negotiations among non-central governments who are not neighbors, but whose national governments are. Finally, global paradiplomacy consists on political-functional contacts with distant nations that connect non-central governments not only with commercial, industrial, or cultural centers in other continents, but also with different branches or agencies of foreign national governments (Duchacek, 1990, pp. $18-27$ ).

Some authors, such as Nossal, Rousell and Paquin (2015) distinguish between paradiplomacy and protodiplomacy. Paradiplomacy refers to international activities of a non-central government that are conducted together with the diplomacy of central government. In contrast, protodiplomacy is implemented by a non-central government that seeks to use its international activities to gain recognition from other States, and thus to transform proto-diplomacy into pure and simple diplomacy, through the achievement of independence and sovereignty at the State Level. In Quebec, there have been sporadic episodes of protodiplomacy, such as the one in the late 1970s and mid-1990s. However, at present, the international activities of the provincial government have been aimed at ensuring against the independence for Quebec as a sovereign State, but a paradiplomacy that strengthens Québécois identity (Nossal et al., 2015).

In respect to Canada, Vengroff and Rich (2006) claim that the increase in paradiplomacy is the result of several key factors, such as: "growing 
globalization, international trade agreements (...), the current impact of federalism, nationalism, decentralization, constitutional provisions (somewhat ambiguous) and the expansion of international activity in areas reserved for subnational units" (pp. 106-107). They are considered some of the most important factors.

In the case of the United States, there has been an increase in international activities of the states over the last two decades. For example, only four States in the United States had permanent representations abroad in 1980, while in 2002 , this number increased to almost 40 of the 50 states of this country, in this way, the number of this type of office increased from 151 in 1992 to 240 in 2000 (Scholte, 2005, p. 205).

Considering these circumstances, it can be noted that traditional diplomatic activities, conducted by national governments, have not been enough to solve the problems of the region. Global problems such as migration, security, pollution, climate change, among others, are not being addressed effectively at a national level. As a result, subnational states have become avenues for solutions and proposals for the most serious and complex global problems for the early 21 st century.

The following section focuses on paradiplomacy of Canadian provinces, precisely because, as it has been pointed out, Canada is the country where these trends are the most relevant due to its highly decentralized federal political system

\section{Dimensions of paradiplomacy in Canadian provinces}

In Canada, provincial governments are generally free to act internationally within their areas of competence as described in the Canadian constitution, and the national government is expected to consult with the provinces before entering into any international treaty that affects the provinces in their areas of concern (Fry, 2011). All Canadian provinces have developed relationships with neighboring states in the United States to solve common problems and manage resources, as well as, promote economic exchanges and attract investment.

In other regions of the world, similar dynamics are also observed. Fry (2011) states that the Flemish region in Belgium, Catalonia and the Basque Country in Spain, and Quebec in Canada have the most active international relations programs, in terms of money paid and personnel dedicated to international activities. The Canadian province with the highest level of international relations is Quebec, followed by Alberta, Ontario and British Columbia

According to Lecours (2009: 127), the international activity of the Canadian provinces is mainly functional, since it responds to economic interests, for the 
promotion of exports and the attraction of foreign investment, as well as, information sharing and sometimes directing public policies with neighboring states of the United States. In fact, the provincial governments of Canada spend more on international programs and have more personnel involved in such programs than the total of all 50 States of the United States, even though, the provinces collectively represent a ninth of their population and corresponds to one fourteenth of the United States Gross Domestic Product (Fry, 2004, p.12). Likewise, some Canadian cities such as Montreal (Quebec), Vancouver (British Columbia) and Toronto (Ontario) have also developed an international dimension (Lecours, 2009, p. 128).

Vengroff and Rich (2006) reveal that Quebec has been the most active province in terms of paradiplomatic activities (p. 119). These authors emphasize Quebec's dimension of paradiplomacy: this province has a department with personnel exclusively dedicated to international relations. Since 1964, Quebec has signed more than 550 international agreements and more than 300 are still valid with 79 different countries. Vengroff and Rich (2006) also state that this province has a significant presence abroad, with a network of 28 offices in 17 countries including the United States, Latin America, Europe and Asia (2006, p. 119). In addition, Quebec has created its own Ministry of International Relations with more than 550 employees and an annual budget that exceeds 100 million dollars (Fry, 2011).

On the other hand, the involvement of subnational governments in the international field among the countries of North America is evident; however, it is convenient to observe that in some cases these relations have been institutionalized between cross-border states of the countries in the region, creating forums and conferences, which become periodic spaces of transnational cooperation. There are various approaches of transnational cooperation between border states in the region that is valid to note. The next section focuses on the mechanisms of interaction between the subnational governments of the region, mainly the border region between Canada and the United States, as well as, the United States and Mexico.

\section{Cross-border paradiplomacy in North America}

Within a political context, characterized by decentralized federal government systems, NAFTA has helped to strengthen political and institutional ties between the provinces of Canada and the states of Mexico and the United States. Several cross-border organizations have been created to facilitate greater regional cooperation among non-central governments. 
Some Border states in North America that face common problems have formed forums and permanent working groups. For example, the four southern states of the United States (California, Arizona, New Mexico and Texas) and the six northern states of Mexico (Baja California, Sonora, Chihuahua, Coahuila, Nuevo Leon, and Tamaulipas) have held joint meetings periodically to sign cooperation agreements on varied topics such: economic development, commercial ports, education, health and safety, among others (Embassy of Mexico in the United States, 2012). This forum is known as the Border Governors Conference.

The first Border Governors Conference was held in the city of Juárez, Chihuahua, Mexico in 1980. It started a formal process of opening lines of communication between the ten border states of the United States and Mexico. Periodic conferences have been dealt alternating venues between USA and Mexico (Arizona Government, 2016). Other examples of cooperation between subnational states of these two countries include Mexico-Arizona Commission, Border Governors Conference, Border Legislators Conference, Chihuahua-New Mexico Border Commission, and Commission of the Californias (McMillan, $2012)$.

Similarly, there are several sets in which relations between subnational governments in the United States and Canada have been institutionalized. McMillan (2012) notes that economic and trade globalization enhanced crossborder links of those states from USA that border Canada or Mexico. It involves them in varying matters, such as trade, border security, immigration and environmental problems. Cross-border organizations have been created, such as New England Governors Commission and Eastern Canadian Prime Ministers, the Great Lakes Board of Governors (CGLG), Idaho Special Forces Alberta, Council Bilateral Consultative Montana- Alberta, the Pacific Northwest Economic Region, and the Association of Western Governors and Western Canadian Prime Ministers (McMillan, 2012, p. 78) Some of these regional organizations will be described:

a) Conference of Governors and Premiers of the Great Lakes and St. Lawrence.

This conference was founded in 1983, it is made up of the following members: in the United States, the states of Illinois, Indiana, Michigan, Minnesota, New York, Ohio, Pennsylvania and Wisconsin; and in Canada, the provinces of Ontario and Quebec. Through the Conference, Governors and Premieres work to grow the region's economy, estimated to be worth around $\$ 5$ trillion, 
and protect the largest freshwater system in the world (CGLSLGP, 2016) . The $^{2}$ Conference is the result of more than 30 years of work by the Great Lakes Council to stimulate and facilitate responsible economic development with the environment

b) The Conference of Governors of New England and Premiers of Eastern Canada.

The Conference of Governors of New England and the Premiers of Eastern Canada represent much of the cross-border activity in the region. This conference as one of the oldest cross-border regional mechanisms was established in 1976 and has devoted special attention to issues such as sustainable development and environment. Likewise, the member states have formulated actions to reduce air pollution and greenhouse gases ${ }^{7}$. Its founding members are made up of 11 subnational governments: five Provinces of Canada (New Brunswick, Newfoundland and Labrador, Nova Scotia, Prince Edward Island and Quebec) and six states of the United States (Connecticut, Maine, Massachusetts, New Hampshire, Rhode Island and Vermont).

c) Alliance between states of the Southeast of the United States and the Canadian Provinces (SEUS-CP).

The strategic partnership between the states of the southeastern United States and the Provinces of Canada was established in 2007 in Montreal, Quebec, with the objective of promoting trade and investment opportunities between the member states and the provinces. The member states include Alabama, Georgia, Mississippi, North Carolina, South Carolina and Tennessee of the United States and the provinces of Manitoba, New Brunswick, Newfoundland and Labrador, Nova Scotia, Ontario, Prince Edward Island and Quebec of Canada. The Alliance meets at an annual conference headed by the governors of each state, and Premieres or their representatives (business and industry leaders).The conference allows the leaders of southeastern Canada and the United States to negotiate with a network of public and private sector leaders. The most relevant topics addressed are: new communication technologies, advanced manufacturing and clean technology (SEUS-CP, 2016).

\footnotetext{
6. For further information about this Conference. See. http//:www.cglslgp.org

7. For more details about this Conference, see Robert G. Healy, Debora Van Nijnatten, and Marcela Lopez-Vallejo. 2014 Environmental policy in North America: Approaches, capacity, and the management of transboundary issues. University of Toronto Press.
} 
d) Council of State Governments - Eastern Regional Conference (CSG-ERC).

The purpose of the Eastern Regional Conference (CSG-ERC) is to facilitate the exchange of ideas among policymakers, business leaders and the academic community of 18 member states. These subnational governments include the 11 northeastern states of USA from Maine to Maryland, Puerto Rico, and Virgin Islands; and in Canada, the provinces of Quebec, New Brunswick, Ontario, Nova Scotia and Prince Edward Island. The headquarters office of this conference is located in New York, since 1937.

For more than 70 years, members of this conference have tried to train public officials in relation to the problems and challenges that the region faces. This forum promotes multi-state or regional solutions to common problems by facilitating the cooperation among its members. In carrying out its mission, the research and analysis of public policies are carried out; seminars and conferences are organized and electronic bulletins related to various topics such as agriculture, energy/environment, health, transport and regional trends are published.

Recently, the Premiers of Canada met with the governors of the United States and Mexico. In 2015, the First Summit of Governors and Premiers of North America took place in Colorado, United States. Seven governors from the United States, six governors from Mexico and two from Canada participated in the event. The objective was to promote cross-border dialogue in search of joint actions and opportunities in the economy, politics, energy, sustainable development and environment.

On behalf of Mexico, the governors of six states (Hidalgo, Jalisco, Puebla, Quintana Roo, Yucatan and Mexico) attended the National Conference of Governors (CONAGO). The governors of Colorado, Utah, Michigan, South Dakota, New Mexico, the Virgin Islands and Illinois participated as members of the National Governors Association of the United States (NGA), and the Canadian premiers of Yukon and New Brunswick participated as representatives of the Council of the Federation of Canada, COF (National Governors Association, 2015). It was a joint meeting of the three associations that bring together the subnational authorities of the three countries that belong to the North American region.

On this basis, it can be noted that the international relations of the subnational states between North American countries are not concentrated only between border states (cross border regional paradiplomacy), but also organizations and cooperation forums have been created between distant subnational states, but from neighboring countries (transregional paradiplomacy). In addition, there 
are other cases of international relations between subnational states of distant countries (global paradiplomacy). In recent years, the number of international offices in Canadian provinces has grown in Asian countries, especially in China.

A review of the characteristics of paradiplomatic relations in the cases analyzed above, allows us to demonstrate the participation not only of subnational governments (governors and premieres) within the regional organizations, but also of business and industrial leaders, as well as a network of leaders of public and private sector and the academic community, with the aim of making joint decisions. Similarly, the influence of non-governmental organizations on the topics discussed in conferences and organizations, the environment and sustainable development stand out.

As shown, the Border Governors Conference is the most relevant case of cross-border regional paradiplomacy between the United States and Mexico. However, the meetings in the framework of this conference have decreased in recent years. However, it is relevant to emphasize that the cooperation between some border states has increased bilaterally. The case of Arizona and Sonora is highlighted, it has 14 inter-institutional cooperation agreements on various issues such as economic development, labor, security, tourism, arms trafficking, and people, among others (SRE, 2016).

\section{Conclusions}

Several subnational states have increased their international activities in order to promote their interests abroad, mainly the promotion of trade and the attraction of foreign investment. In addition, cooperation agreements in areas such as environment and sustainable development, among others have been dealt with. Most of the agreements and policies that have been arranged become part of the jurisdiction areas of the subnational governments, and at the same time, reveal a degree of their autonomy in respect to the central government.

The specific forms of international activities of subnational governments are mainly concentrated in establishing representative offices abroad, likewise, cooperation agreements have been signed with other states in the region. The relevance of international activities of subnational governments is crucial, since many of local problems are being addressed in these transnational cooperation spaces between subnational actors from different countries.

The growing economic integration in North America has facilitated other forms of integration through the actions undertaken by subnational governments. It has occurred, due to the fragmentation of central government power, which has emerged of various sources of authority, both nationally and 
internationally. Within the new governance of the region, the participation of subnational governments in spaces of transnational cooperation with other subnational units, which sometimes become institutional forums: These forums have brought together states and provinces of the United States and Canada in order to coordinate efforts to face common challenges in various areas.

Most of the international activities of subnational states, such as agreements and other cooperation schemes, are considered in the scope of their constitutional powers. However, in some cases subnational governments pursue independent goals of subnational governments, especially those provinces that are considered as a nation within a State, such as the case of Quebec in Canada, although in recent years this trend has diminished.

Finally, it is clear that subnational governments contribute significantly to the governance of North America through the formulation of regional public policies to address the common challenges faced by subnational states in a region. Many of these agreements are limited in the areas of jurisdiction of the subnational governments and reveal a certain degree of autonomy with respect to the central government.

Some of the cases of cooperation among subnational governments analyzed in this paper, present new schemes that can serve as an example for other Latin American countries that become part of regional blocks such as Mercosur, among others, that have become favorable contexts for cooperation between subnational governments in this region.

\section{References}

Arizona Government (2016). Border Governors Conference. Recuperado de: https://tourism.az.gov/border-governors-conference.

Balthazar, L. (1999). The Quebec experience: Success or failure? Regional \& Federal Studies, 9(1): 153-169.

Bélanger, C. (2008). Canadian Federalism -Division of Powers (ss. 91-95 of the Constitution Act 1867). Marianopolis College. Recuperado de: http://faculty.marianopolis.edu/c.belanger/QuebecHistory/readings/Canadadivisionofpowers.html

Burgess, M. (2006). Comparative federalism: Theory and practice. Londres-Nueva York: Routledge. 
Curzio, L. (2000). El federalismo mexicano: balance y perspectivas. En G. Ibarra y A. L. Ruelas (eds.). México y Canadá en la globalización: fronteras tensionadas en América del Norte (pp. 257-280), México: Porrúa.

Conference of Great Lakes and St. Lawrence Governors and Premiers (CGLSLGP), (2016). Recuperado de: http://www.cglslgp.org/

Cornago, N. (2013). Diplomacy and Paradiplomacy in the Redefinition of International Security: Dimensions of Conflict and Cooperation. En Aldecoa, F. (Ed.) Paradiplomacy in Action: The Foreign Relations of Subnational Governments (pp. 40-57), Londres-Nueva York: Routledge.

The Council of State Governments Eastern Regional Conference (CSG/ERC). Recuperado de: http://www.csg-erc.org/

Duchacek, I. (1990). Perforated Sovereignties: Towards a Typology of New Actors in International Relations. En Hans J. Michelmann y Panayotis Soldatos (Eds.). Federalism and International Relations: The Role of Sub-national Units. Oxford: Clarendon Press.

Embajada de México en Estados Unidos (2012). El Embajador Arturo Sarukhán participa en XXX Conferencia de Gobernadores Fronterizos en Albuquerque, Nuevo Mexico. Recuperado de: http://embamex.sre.gob. $\mathrm{mx} /$ eua/index.php/es/comunicados2012/591-el-embajador-arturo-sarukhan-participa-en-xxx-conferencia-de-gobernadores-fronterizos-en-albuquerque-nuevo-mexico, consultado en octubre de 2014.

Fry, E. H. (2011). Federalism and Foreign Relations. En George T. Kurian, James E. Alt, Simone Chambers, Geoffrey Garret, Margaret Levi, Paula D. Mcclain (Eds.) The Encyclopedia of Political Science. California: CQPress (pp. 573-574).

Fry, E. H. (2004). The Role of Sub-National Governments in North America Integration. Thinking North America. Canada: Institute for Research on Public Policy.

Fry, E. H. (2005). Sub-State strategies in an era of globalization and the information technology revolution. En S. Paquin y G. LaChappelle (Eds.). Mastering globalization: new sub-states' governance and strategies (pp. 116-123). Londres-Nueva York: Routledge. 
Hale, G. (2012). So near yet so far: The public and hidden worlds of Canada-US relations. Canada: UBC Press.

Healy, R. G. et al. (2014). Environmental policy in North America: Approaches, capacity, and the management of transboundary issues. University of Toronto Press.

Heywood, A. (2010). Global politics. Basingstoke: Palgrave Macmillan.

Hague, R. y Harrop, M. (2004). Comparative government and politics. Londres: Palgrave Macmillan.

Hocking, B. (1993). Localizing foreign policy: Non-central governments and multilayered diplomacy. Springer.

Kincaid, J. (2013). The international competence of US states and their local governments" en F. Aldecoa (ed.), Paradiplomacy in action: the foreign relations of subnational governments, Londres - Nueva York: Routledge, pp. 111-133.

Kuznetsov, A. (2014) Theory and Practice of Paradiplomacy. Londres - Nueva York: Routledge.

Kukucha, Ch. J. (2008). The provinces and Canadian foreign trade policy. Vancouver: UBC press.

Lecours, A. (2009). Canada. En Hans Michelmann (Ed.) Foreign Relations in Federal Countries (pp. 114-139). Montreal y Kingston -Londres, Ithaca: McGill-Queen's University Press, Forum of Federations

Márquez-Padilla, P.C. (2012), Justicia Internacional: ideas y reflexiones, México, CISAN-UNAM.

Pierre J. (2013). Globalization and governance. Edward Elgar Publishing.

McHugh, J. (2015). Paradiplomacy, protodiplomacy and the foreign policy aspirations of Quebec and other Canadian provinces", Canadian Foreign Policy Journal, 21(3), 238-256.

McMillan, S. L. (2012). The Involvement of State Governments in U.S. Foreign Relations. Nueva York: Palgrave Macmillan. 
Naím, M. (2013). El fin del poder. Bogotá: Debate.

National Governors Association, (2015). North American leaders meet for firstever Summit. Recuperado de: http://www.nga.org/cms/home/newsroom/news-releases/2015--news-releases/col2-content/north-american-leaders-summit.html

Nossal, K. R. et al (2015). The politics of Canadian foreign policy. McGill-Queen's Press-MQUP.

OCDE (2013) Estudios Económicos de la OCDE: México 2013, Centro de la OCDE para América Latina.

OECD (2015) Government at a Glance 2015. Paris: OECD.

Paquin, S. (2010). Federalism and compliance with international agreements: Belgium and Canada compared. The Hague Journal of Diplomacy 5(1-2), 173-197.

Paquin, S. y LaChappelle, G. (2005). Introduction. En S. Paquin y G. LaChappelle (Eds.). Mastering globalization: new sub-states' governance and strategies. Londres-Nueva York: Routledge.

Rosenau, J. N. (2003). Governance in a new global order. En D. Held y A. McGrew (Eds.). Governing Globalization: Power, Authority and Global Governance (pp. 70-86). Cambridge-Malden: Polity Press.

Rosenau, J. N. (2006). The Study of World Politics: Globalization and Governance. Londres - Nueva York: Routledge.

Scholte, J. A. (2005) Globalization: a critical introduction. Houndmills Basingstoke -Nueva York: Palgrave MacMillan.

Secretaria de Relaciones Exteriores (SRE) (2014). América del Norte del Siglo XXI: construyendo la región más Dinámica y Competitiva del Mundo. Recuperado de: http://saladeprensa.sre.gob.mx/index.php/es/comunicados/3728-050

Secretaria de Relaciones Exteriores (SRE) (2016). Gobiernos Locales. Recuperado de: http://www.sre.gob.mx/coordinacionpolitica/index.php/diplomacia-local 
Southeastern United States -Canadian Provinces Alliance (SEUS-CP) (2016). REcuperado de: http://seuscp.com/us/

United Nations for Development Programme (UNDP) (2004). Decentralized governance for development. A combined practice note on decentralization, local governance and urban / rural development. Nueva York: UNDP.

United States Embassy in Mexico, (2014). Bilateral Trade fact-Sheet. http:// photos.state.gov/libraries/mexico/310329/july2014/2014_07_Bilateral\%20Trade.pdf

Vengroff, R. y Rich, J. (2006). Foreign policy by other means: Paradiplomacy and the Canadian provinces. En P. James, N. Michaud y M. J. O’Reilly (Eds.). Handbook of Canadian Policy (pp. 105-130). Toronto: Lexington Books.

Zürn, M. et al. (2010). Introduction. En H. Enderlein, S. Wälti y M. Zürn (Eds.). Handbook on multi-level governance (pp. 1-13). Cheltenham: Edward Elgar.

Zepeda, R. (2013). Neoliberalismo, desempeño económico y mercados laborales en Latinoamérica: un enfoque comparativo. Ánfora, 20(35), 13-40. Universidad Autónoma de Manizales. 